\title{
Some aspects of pod characteristics predisposing pigeonpea (Cajanus cajan (L.) Millsp.) to infestation by Callosobruchus chinensis (L.)
}

\author{
M. Silim Nahdy ${ }^{\mathrm{a}, *}$, S.N. Silim ${ }^{\mathrm{b}}$, R.H. Ellis ${ }^{\mathrm{c}}$ \\ ${ }^{a}$ Kawanda Agricultural Research Institute, P.O. Box 7065, Kampala, Uganda \\ ${ }^{\mathrm{b}}$ International Crops Research Institute for the Semi-Arid Tropics (ICRISAT), P.O. Box 39063, Nairobi, Kenya \\ ${ }^{\mathrm{c}}$ The University of Reading, Department of Agriculture, Earley Gate, P.O. Box 236, Reading, RG6 2AT England
}

Accepted 3 July 1998

\begin{abstract}
Investigations with pigeonpea (Cajanus cajan) genotypes 'Apio-elina' and 'PI-397566' showed that certain pod characteristics influenced both infestation in the field by Callosobruchus chinensis and damage caused by this pest. Compared to pods with no or sparse hair, pods with thick hairs suffered greatly reduced field infestation due to the barrier effect of the hairs on oviposition and larval penetration. Even on pods with no or few hairs, the pod wall appeared to offer some resistance to both larval penetration and adult emergence. High levels of infestation by $C$. chinensis were recorded on pigeonpea pods with no or few hairs, those with pods damaged through shattering, and those with pods that had been previously damaged by pod borers. From the results of the study, it was recommended that pigeonpea selection should include screening for high pod hair density and thicker pod wall. (C) 1998 Elsevier Science Ltd. All rights reserved.
\end{abstract}

Keywords: Pigeonpea (Cajanus cajan); Callosobruchus chinensis; Field infestation; Pod trichomes

\section{Introduction}

In East Africa, pigeonpea (Cajanus cajan (L.) Millsp.) is the second most important grain legume after beans (Phaseolus vulgaris L.) with about 133,000t produced each year from over 249,000 ha (Nene et al., 1990). Pigeonpea productivity is, however, low mainly because it is

\footnotetext{
* Author for correspondence.
} 
often grown under poor agronomic conditions, exposed to drought stress, and subjected to losses due to pests and diseases (Tuwafe et al., 1994). In the field, the most serious insect pests are pod borers (Helicoverpa armigera Hubner and Maruca testulalis Geyer), pod sucking bugs (Clavigralla spp.) and podfly (Melanagromyza spp) (Minja et al., 1996). In storage, bruchids (Coleoptera: Bruchidae) are the major source of losses to pigeonpea (Singh and Jambunathan, 1990). Among the Bruchidae, the genus Callosobruchus cause greatest damage (Mphuru, 1978; Lateef and Reed, 1990; Singh and Jambunathan, 1990). In India, the most common species infesting pigeonpea are; Callosobruchus chinensis (L.), C. maculatus (L.) and C. analis (F.) (Babu et al., 1989; Singh and Jambunathan, 1990; Bhaduri et al., 1990; Khaire et al., 1992). In East Africa (Le Pelley, 1959, Davies 1960, Mphuru, 1978), both C. chinensis and C. maculatus infest pigeonpea; in addition, C. analis and Callosobruchus rhodesianus(F.), were reported on pigeonpea in Tanzania (Mphuru, 1978). In Uganda, although earlier studies indicated that both C. chinensis and C. maculatus are pests of stored pigeonpea (Davies, 1960), it is now known that the former is the major cause of damage (Silim Nahdy et al., 1997).

In the field, infestation by Callosobruchus starts by the adult ovipositing on mature pods, but when the seeds are subsequently stored, there is greater level of oviposition (Booker, 1967; Taylor, 1981; Yoshida, 1990). Field infestation is characterised by its insidious nature (Taylor, 1981; Silim Nahdy, 1995); eggs are usually glued on the maturing or drying pods, the young first-instar larvae bore into pods and seeds and, at threshing, seeds either show slight or no apparent external damage (Booker, 1967; Caswell, 1968; Southgate, 1978). Although infestation and damage in the field is generally low, such infestation nevertheless has serious implications: the insects multiply rapidly within a short time with heavy consequent damage once the infested seeds are stored (Taylor, 1981).

Field infestations of pigeonpea, by $C$. maculatus and $C$. chinensis have been reported in Hawaii (Bridwell, 1918). In Uganda, studies have shown that the dominant field-to-storage insect pest of pigeonpea is C. chinensis (Silim Nahdy, 1995), and that the two forms, flight and flightless, which are adapted to field and storage conditions respectively, are responsible for the field-to storage cycle and vice versa. The level and mode of field infestation, as well as factors influencing field infestation, are poorly known, but the information is needed if a comprehensive Integrated Pest Management (IPM) package is to be developed.

Because of the heavy damage to pigeonpea seeds, various management options are recommended and practised, all of which target infestations during storage. These include the use of synthetic and non-synthetic pesticides, biorationals, physical and cultural practices (Taylor, 1981). Apart from early harvest (van Huis, 1991), no other strategies have been recommended for field management of bruchid infestation.

The objective of this study was to determine the factors influencing field infestation of pigeonpea by $C$. chinensis in order to derive pigeonpea management packages that include field interventions. This involved field and laboratory investigations to determine the effect of the physical characteristics of the pod on infestation and the relationships between certain pod and seed characteristics and $C$. chinensis infestation. 


\section{Materials and methods}

Three studies were conducted to determine the effect of pod characteristics on infestation by C. chinensis. The objective of trials 1 and 2 was to determine, under artificial and natural conditions respectively, the effect of physical pod characteristics on infestation, while that of trial 3 was to determine the significance of pigeonpea pod trichomes on $C$. chinensis infestation.

The $C$. chinensis adults used in the study were reared on seeds of the pigeonpea landrace "Apio-elina". The original insect cultures were obtained from infested pigeonpea seeds (Apioelina) freshly collected from northern Uganda. The cultures were renewed every two generations, i.e. there was no selection by repeated laboratory culture at Kawanda Agricultural Research Institute (KARI). All adults were cultured in the laboratory under ambient conditions (about $23-26^{\circ} \mathrm{C}$ ). In all cases, 2-day-old adults were used to obtain the maximum oviposition rate. Sexing was done using the antennal shape (Southgate, 1978).

In all the trials, the medium-duration local land-race variety "Apio-elina" originating from Lira/Apac was used. This variety was selected due to its low susceptibility to $C$. chinensis infestations (Silim Nahdy, 1995). All the pods and seeds used were grown within KARI, $12 \mathrm{~km}$ north of Kampala $\left(0.4^{\circ} \mathrm{N}, 32.5^{\circ} \mathrm{E}\right.$ and about $1150 \mathrm{~m}$ altitude). All investigations were conducted at the PR-7 (mature dry pod 'late') pod stage (Silim Nahdy et al., in press).

\subsection{Experiment 1: effect of pod characteristics on C. chinensis infestation under artificial infestation}

Studies were conducted on six different physical pod features in order to determine their effect on infestation viz; (a) Normal pods (with stipes), (b) Non-hairy pods, (c) Pods without stipes, (d) Partially dehisced pods, (e) Pods with one hole made by pod borer, (f) Pods with holes made by podfly. Categories (b) and (c) were produced artificially, by lightly scraping hairs in (b) and breaking the stipe stem in (c), respectively. All the other categories of pods were harvested with the desired features already present.

Five pods of each category, replicated eight times, were placed in $50 \mathrm{ml}$ glass jars and infested with five pairs (male and female) of 2-day-old C. chinensis for 4 days and the number of eggs laid on each pod was counted. After an incubation period of 60 days, the total number of adults emerging from pods was recorded. Data were analysed using two-way analysis of variance and the means separated using Duncan's multiple range test.

\subsection{Experiment 2: effect of pod damage on C. chinensis infestation under natural infestation}

Surveys were conducted at pigeonpea harvest in the Apac (October, 1992), Lira (October, 1992) and Gulu (January, 1993) districts of northern Uganda. In each district, three counties were randomly selected for study, and from each county, 10 fields were selected randomly for the survey. Thus, a total of 30 pod samples were collected per district, with each sample weighing between 2 and $3 \mathrm{~kg}$, having been hand picked from various points within the fields.

Pods from each sample were first sorted into five physical categories; undamaged, podfly damaged, pod borer (H. armigera) damaged, pod sucking bug damaged (shrivelled) or physically damaged (split and broken). The sorted pods were shelled separately and seeds 
weighed. The weights of seeds in each category were standardised to $40 \mathrm{~g}$ (this was the weight of the smallest category) by coning and quartering. The samples were incubated for 60 days in $100 \mathrm{ml}$ glass jars under ambient conditions and emerged adults counted. Comparison of adult emergence was performed using one-way analysis of variance and the treatment means were separated using Duncan's multiple range test.

\subsection{Experiment 3: C. chinensis oviposition, larval survival and adult emergence on hairy pods and seeds of pigeonpea}

Pods and seeds were investigated to determine the frequency of oviposition on the different surfaces, the extent and nature of surface penetration by first instar larvae and adult emergence. The two genotypes used were Apio-elina (a local land-race) and PI-397566 (from India and obtained from ICRISAT). These had been determined previously as varieties with high pod-hair density and low-pod hair density, respectively (Silim Nahdy, 1995). The three pod surface types used were: high hair density of genotype "Apio-elina" (mean hair count of $32 \mathrm{~mm}^{-2}$ of pod surface), the low hair density of genotype PI-397566 (mean hair count of $19.4 \mathrm{~mm}^{-2}$ ), "Apio-elina" with all hairs scraped, and seeds as control.

Five pods of each category, or 20 seeds (control) of pigeonpea were placed separately in glass jars, replicated four times, and infested with five pairs of 2-day-old C. chinensis. After four days of infestation, pods and seeds were examined for oviposition using the naked eye, and from observations under the microscope, the type of egg attachment to the substrate was recorded. Pod surfaces were examined under the microscope twice a day for 1 week to record the nature of pod penetration, and at the end of the week to determine the extent of first-instar larval penetration and probable survival. Surface penetration was determined after gently removing the eggs. The extent of penetration was classified as shallow or no penetration $(<0.1 \mathrm{~mm})$, deep but unsuccessful $(>0.1 \mathrm{~mm})$ and deep and successful. The pods and seeds were then incubated for an additional 35 days and the number of emerged adults counted. In the case of the pods, the count was done before and after pod shelling.

\section{Results}

\subsection{Experiment 1: effect of pod characteristics on C. chinensis infestation under artificial infestation}

A high oviposition preference was observed on exposed seeds compared to pods (53.2 eggs laid on seeds within dehisced pods and 61.1 within seeds of $H$. armigera damaged pods). The next highest rate of oviposition was on non-hairy pods (mean of 11.5 eggs per five pods). The lowest ovipositional preference was on surfaces of $H$. armigera damaged (0.4) and on surfaces of dehisced pods $(0.5)$ (Table 1). No significant difference $(P>0.05)$ was observed between the number of eggs laid on normal pods, those without stipes and pods with holes made by podfly. On dehisced pods and those damaged by $H$. armigera, most eggs were laid directly on seeds.

The effect of the different physical pod characteristics on $C$. chinensis larval development and eventual adult emergence was significant $(P<0.05)$ (Table 1$)$. The highest adult emergence was 
Table 1

C. chinensis eggs laid, adult emergence and position of emergence from five pods with different physical features

\begin{tabular}{|c|c|c|c|c|c|c|}
\hline & \multicolumn{6}{|c|}{ Pod types } \\
\hline & $\begin{array}{l}\text { Normal } \\
\text { pods }\end{array}$ & $\begin{array}{l}\text { Non-hairy } \\
\text { pods }\end{array}$ & $\begin{array}{l}\text { Pods without } \\
\text { stipes }\end{array}$ & $\begin{array}{l}\text { Dehisced } \\
\text { pods }\end{array}$ & $\begin{array}{l}\text { With } \\
\text { H. armigera } \\
\text { hole }\end{array}$ & $\begin{array}{l}\text { With podfly } \\
\text { holes }\end{array}$ \\
\hline & $\begin{array}{l}\text { Mean N } \\
4.9 \mathrm{~B}\end{array}$ & $\begin{array}{l}\text { of eggs laid } \\
11.5 \mathrm{~A}\end{array}$ & $\begin{array}{l}\text { on five pods } \\
3.9 \mathrm{~B}\end{array}$ & $\begin{array}{c}0.5 \mathrm{C} \\
(53.2 *)\end{array}$ & $\begin{array}{c}0.4 \mathrm{C} \\
(61.1 *)\end{array}$ & $4.5 \mathrm{~B}$ \\
\hline $\begin{array}{l}\text { Position of adult emergence } \\
\text { Externally } \\
\text { Internally }\end{array}$ & $\begin{array}{l}0.1 \mathrm{E} \\
1.1 \mathrm{D}\end{array}$ & $\begin{array}{l}1.0 \mathrm{D} \\
3.0 \mathrm{C}\end{array}$ & $\begin{array}{l}\text { Mean adult emergence: } \\
0.0 \mathrm{E} \\
1.2 \mathrm{D}\end{array}$ & $\begin{array}{c}0.0 \mathrm{E} \\
40.3 \mathrm{~B}^{* *}\end{array}$ & $\begin{array}{c}0.0 \mathrm{E} \\
52.0 \mathrm{~A}^{* *}\end{array}$ & $\begin{array}{l}1.0 \mathrm{D} \\
1.3 \mathrm{D}\end{array}$ \\
\hline Total emergence & $1.2 \mathrm{C}$ & $4.0 \mathrm{C}$ & $1.2 \mathrm{C}$ & $40.3 \mathrm{~B} * *$ & $52.0 \mathrm{~A} * *$ & $2.3 \mathrm{C}$ \\
\hline
\end{tabular}

Statistical analyses were conducted on angular transformed data, but for clarity, means are presented untransformed. Means followed by the same letter are not significantly different at $P>0.05$ by Duncan's Multiple Range Test. *The difference from the value given above is because these eggs were laid internally on seeds, and results were excluded from analysis. **Adults emerged internally, but came out of pods through damage points.

recorded in pods with previous damage, particularly pods with holes made by $H$. armigera (52 adults) and the partially dehisced pods (40 adults). The next highest treatment was the nonhairy pods (11.5 adults), but in this case adult emergence was very much lower. Undamaged pods (normal), and stipeless pods and podfly-damaged pods had the least emergence (Table 1).

On undamaged pods, over $93 \%$ of the adults emerged internally (within pods) (Table 1). Where pods had external injury (by dehiscence or $H$. armigera damage), all adults emerged internally initially but later found their way out through the cracks or holes in the pods.

\subsection{Experiment 2: effect of pod damage on $C$. chinensis infestation under natural infestation}

C. chinensis emergence from seeds of pods with different injury symptoms varied significantly $(P<0.05)$. The highest emergence was observed from seeds in pods previously damaged either by $H$. armigera (5.3 adults $/ 40 \mathrm{~g}$ of seed) or by splitting or breaking ( 4.2 adults $/ 40 \mathrm{~g}$ of seed). Low emergence was recorded from seeds from undamaged (2.0 adults $/ 40 \mathrm{~g}$ of seed) and podfly damaged ( 2.2 adults $/ 40 \mathrm{~g}$ seed) pods, and the lowest emergence recorded from pod sucking bug damaged pods ( 1.5 adults $/ 40 \mathrm{~g}$ seed).

\subsection{Experiment 3: C. chinensis oviposition, larval survival and adult emergence on hairy pods and seeds of pigeonpea}

Three methods of oviposition by females were identified on seeds and pods: eggs glued on surfaces, eggs firmly lodged between hairs, and eggs lodged between cracks on pod surfaces (Fig. 1 and Table 2). The lowest oviposition was recorded on pods with high hair density (five eggs on five pods) followed by pods with low hair density (nine eggs on five pods), and pods 


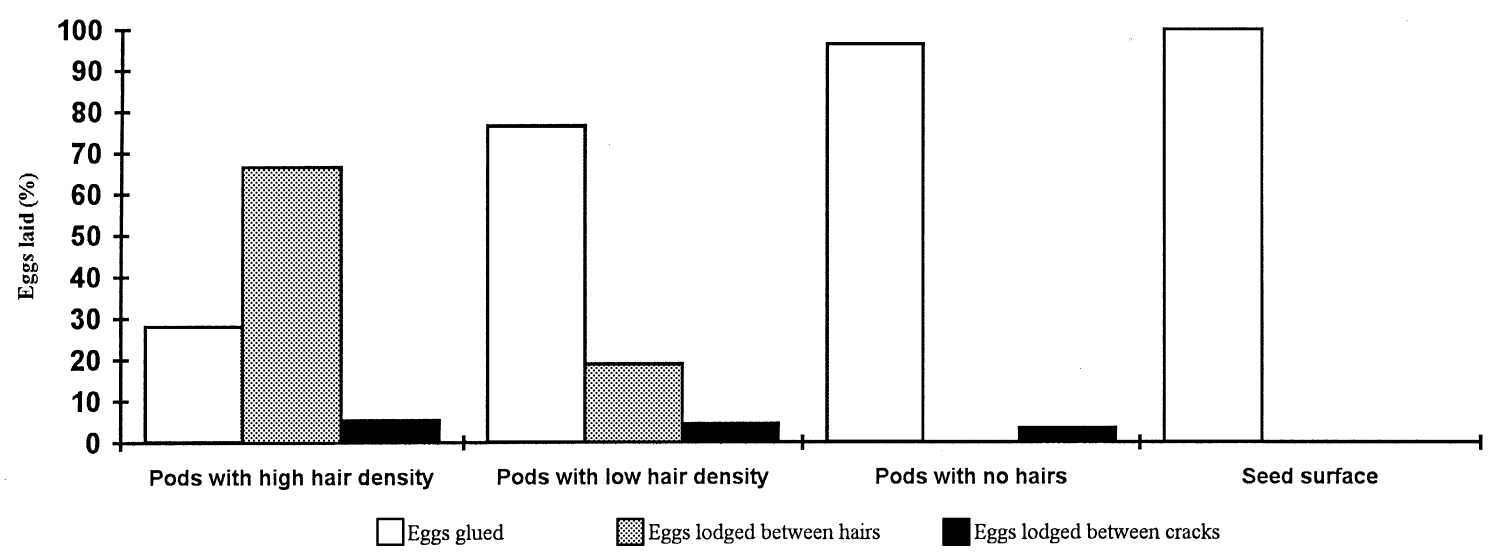

Fig. 1. The effect of pigeonpea surface type on the method of oviposition by C. chinensis

with no hairs (12 eggs on five pods), with oviposition on seeds being the highest (59 eggs on 20 seeds). All oviposition on seeds was by egg gluing. The oviposition on less or non-hairy pods was mostly by eggs being glued, followed by being lodged between hairs or cracks, the last being the least common. The interaction between mode of egg attachment and type of substrate surface was found to be significant $(P<0.05)$. On pods with high hair density (Apio-elina), the commonest mode of oviposition was by egg lodging between hairs, followed by egg gluing and lastly, egg lodging between cracks (Fig. 1 and Table 2). On pods with low hair density (PI397566) or pods with no hairs or seeds, oviposition was mainly by egg gluing (Fig. 1 and Table 2). Some egg lodging between hairs was detected in pods with low hair density, while egg lodging between cracks was detected on low hair density, high density and smooth pods.

The differences between the extent of surface penetration were significant $(P<0.05)$. The interaction between the extent of larval surface penetration and nature of the surface was also significant $(P<0.05)$ (Fig. 2). The highest successful penetration was recorded on seed surfaces followed by pods with smooth surfaces. Deep but unsuccessful hollowing was recorded on pods with high hair density (Apio-elina), low hair density (PI-397566) and those with no hairs, but was less common on seeds. Shallow or no hollowing by larvae was greatest on pods with

Table 2

Nature of $C$. chinensis oviposition and mean number of eggs laid on surfaces of five pods or 20 seeds of pigeonpea

\begin{tabular}{|c|c|c|c|c|}
\hline & $\begin{array}{l}\text { Pods with high } \\
\text { hair density }\end{array}$ & $\begin{array}{l}\text { Pods with low } \\
\text { hair density }\end{array}$ & $\begin{array}{l}\text { Pods with } \\
\text { no hairs }\end{array}$ & $\begin{array}{l}\text { Seed } \\
\text { surface }\end{array}$ \\
\hline Mode of oviposition & No. of eggs laid & & & \\
\hline glued & 1.4 & 6.9 & 11.6 & 59.0 \\
\hline lodged between hairs & 3.3 & 1.9 & 0.0 & 0.0 \\
\hline lodged in cracks & 0.3 & 0.2 & 0.4 & 0.0 \\
\hline Eggs laid & 5.0 & 9.0 & 12.0 & 59.0 \\
\hline
\end{tabular}

SE for Hair density: 0.450SE for Mode of oviposition: $0.457 \mathrm{CV}$ : $54.41 \%$ 


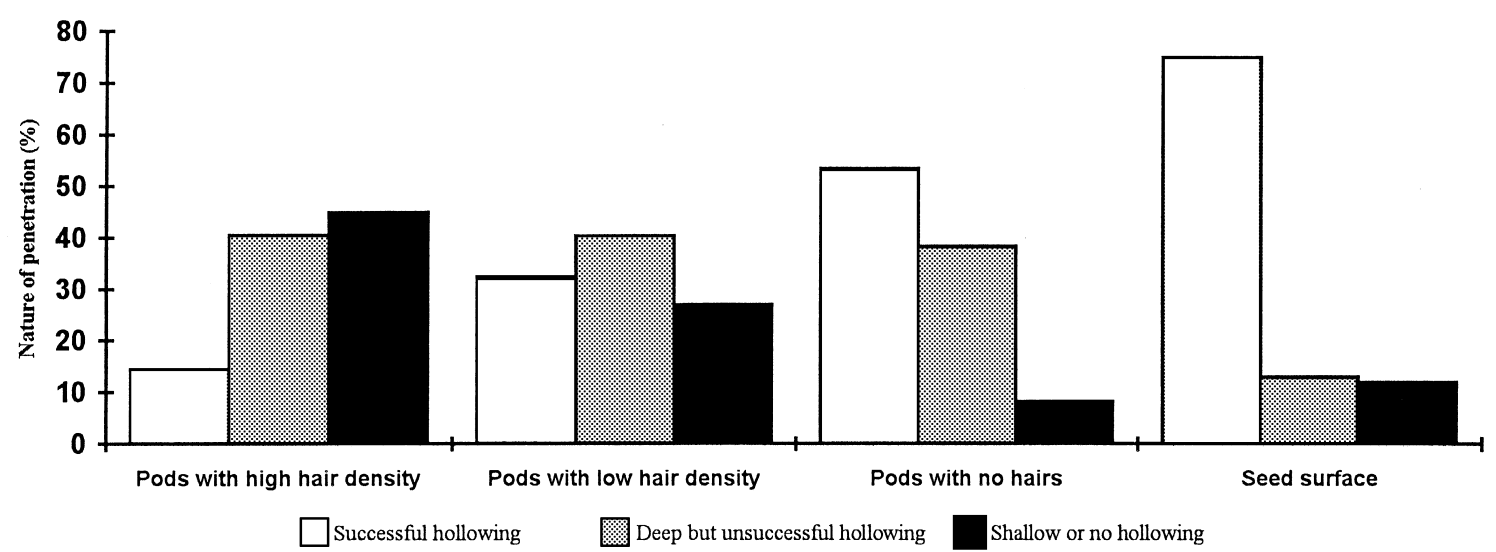

Fig. 2. The effect of pigeonpea surface type on the extent of surface penetration by the 1st instar larvae of C. chinensis.

high hair density and low hair density. In all cases, where penetration was unsuccessful, the larvae eventually died.

When expressed as a proportion of the eggs laid on the surfaces, there was a significant difference in the final percentage of adults that emerged through the different surface types $(P<0.05)$ (Fig. 3). By far, the highest adult emergence was recorded from seeds $(58 \%)$. Although total adult emergence from high hair density (Apio-elina), low hair density (PI397566) and non-hairy pods was low, total emergence from the former was significantly lower $(P<0.05)$ than the rest. From pods with low hair density, and no hairs, fewer $(P<0.05)$ adults emerged externally (through emergence holes on pods) than internally (within pods), and from high density pods no adults emerged externally (Fig. 3).

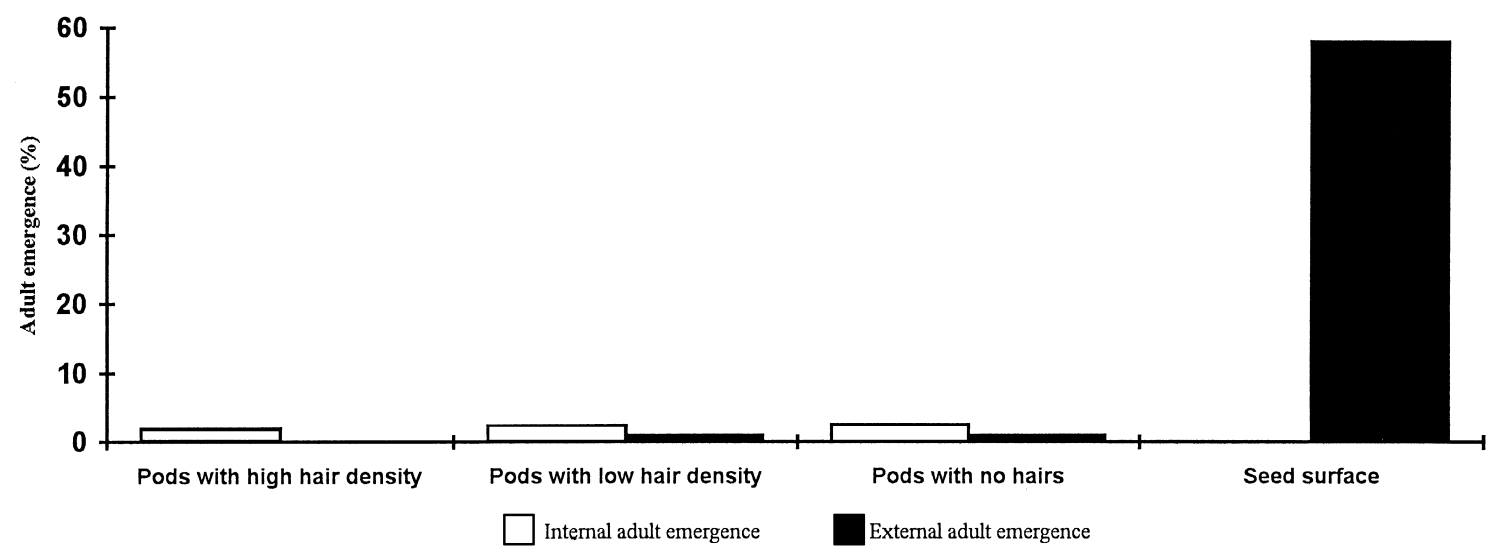

Fig. 3. The effect of pigeonpea surface type on successful adult C. chinensis emergence (\%) and method of emergence. 


\section{Discussion}

Infestation of pigeonpea by $C$. chinensis starts in the field and, once infested seeds are stored, there is rapid pest multiplication and destruction of seeds which may reach $100 \%$ within a very short time (Silim Nahdy, 1995). This is because of the continuous reinfestation of seeds, whereby eggs are laid on the seed surface and the emerging larvae bore inside the seeds, eat and grow and adults emerge from inside the seeds to mate and lay more eggs on the seeds to repeat the process.

The present study showed that pod physical characteristic and damage have a great influence on field infestation and damage by $C$. chinensis. Compared to pods with no hairs and pods with low hair density, pods with high hair density considerably reduced the number of eggs laid by $C$. chinensis. On pods with no or few hairs and seeds, eggs are mostly glued on the surfaces whereas on very hairy pods they were lodged between pod hairs. Gluing on the surface ensures permanent egg attachment and on hatching, infestation of seed is more certain because the young larva has direct contact with the host. It is probable that egg lodgement between hairs or cracks is to ensure that at least some eggs are laid on the host surface. What is not clear is whether, under natural conditions, the eggs lodged between hairs on the pod fall off or stick and hatch to infest the seed within.

In a recent discussion with the largest buyer of pigeonpea in Tanzania, it was learnt that pigeonpea seeds from southern Tanzania are greatly damaged in the field by $C$. chinensis and other Callosobruchus sp. and the result is that the market value of the crop is reduced and at the same time buyers are discouraged from procuring the produce for export. ICRISAT-Kenya has in its germplasm collection a large number of genotypes from southern Tanzania. The pods of these genotypes are thin and smooth (Said Silim, pers. comm.), traits which this study has shown result in higher susceptibility to infestation by $C$. chinensis. ICRISAT-Kenya has now assembled a large number of pigeonpea genotypes and has begun to screen for pod hairiness, in addition to high seed yield and large seeds of cream colour. Such genotypes will be sent to southern Tanzania for further testing to ascertain whether or not they are resistant to field infestation by $C$. chinensis.

In addition to the number of eggs that are attached successfully to the pod surface, the ability of newly hatched $C$. chinensis to penetrate successfully into the pod is equally important in ensuring the success of infestation, with low penetration recorded on hairy pods (Fig. 2). Pod thickness has also been shown to reduce larval penetration (Silim Nahdy, 1995), and the two attributes; pod thickness and hairiness, are obviously important factors influencing the level of field infestation. It is easy to score pods for hairiness visually and probably it is equally possible to determine the length of hairs. Pod thickness can also be determined visually without the use of expensive equipment. We suggest that a scoring system for pod hairiness and thickness in pigeonpea genotypes would be a useful step in estimating susceptibility.

The studies have shown that $C$. chinensis prefers laying eggs on seeds of pigeonpea (Table 2), and factors that expose seeds within the pod to the outside tend to cause the pest to lay eggs directly inside the pod (Table 1). The factors that permitted the pest to lay eggs inside the pod included damage to the pod by pod borer and pod-splitting. Damage by the pod borer is caused when pods are young and are less fibrous, while the pods split or shatter when they are mature and dry. In both cases, the size of the hole/damage would allow adult entry into and 
emergence from the pod and subsequent reinfestation. Although there was some $C$. chinensis infestation of podfly infested pigeonpea, this was very low, probably because the holes caused by the podfly were too small to permit adult $C$. chinensis entry and emergence. Pesticides, if used in the field, have been found to reduce or eliminate field pest damage on pods and have the additional advantage of controlling field infestation by C. chinensis (Silim Nahdy, 1995). Shattering is a trait routinely selected against by ICRISAT pigeonpea breeders (Said Silim, pers. comm.). Selecting clean pods that have not shattered may be one of the ways farmers could increase the duration for which pigeonpea can be stored without damage by $C$. chinensis.

\section{References}

Babu, T.R., Hussein, S.H., Sayanarayna, B., 1989. Effect of pre-storage seed treatment on adult mortality, oviposition and development of Callosobruchus chinensis L. (Bruchidae:Coleoptera), and the viability of mung bean (Vigna radiata (L.) Wilczek) in India. Tropical Pest Management 34, 397-398.

Bhaduri, N., Gupta, D.P., Shri-Ram, N. 1990. Effects of vegetable oils on the ovipositional behaviour of Callosobruchus maculatus (Fab.) In: Bruchids and Legumes: Economics, Ecology and Co-evolution. Fujii, K. (Ed.), pp. 81-84. Kluwer Academic Publishers, The Hague, Netherlands.

Bridwell, J.C., 1918. Notes on Bruchidae and their parasites in the Hawaiian Islands. Hawaii Entomological Society Proceedings 3, 405-505.

Booker, R.H., 1967. Observations on three bruchids associated with cowpea in Northern Nigeria. Journal of Stored Products Research $3,1-15$.

Caswell, G.H., 1968. The storage of cowpea in northern Nigeria, Annual Report of the Institute of Agricultural Research. Samaru, Zaira, Nigeria, pp. 4-6.

Davies, J.C., 1960. Coleoptera associated with stored products in Uganda. East African Agricultural and Forestry Journal 25, $199-201$.

Khaire, V.M., Kachare, B.V., Mte, U.N., 1992. Efficacy of different vegetable oils as grain protectants against pulse beetle, Callosobruchus chinensis L. in increasing storability of pigeonpea. Journal of Stored Products Research 28, $153-156$.

Lateef, S.S., Reed, W. 1990. Insect pests of pigeonpea. In: Insect Pests of Tropical Food Legumes. Singh, S.R. (Ed.), John Wiley and Sons Ltd., Chichester, UK. pp. 194-242.

Le Pelley, R.H., 1959. Agricultural Insects of East Africa. East African High Commission, Nairobi, Kenya, 307.

Minja, E.M., Shanower, T.G., Songa, J.M., Ong'aro, J.M., Mviha, F.A., Myaka, F.A., Okurut-Akol, H. 1996. Pigeonpea seed damage from insect pests on farmers' fields in Kenya, Malawi, Tanzania and Uganda. ICPN 3. ICRISAT-SEA, P.O. Box 39063, Nairobi, Kenya: International Crops Research Institute for the Semi-Arid Tropics.

Mphuru, A.N. 1978. Occurrence, host plants and relative importance of Callosobruchus spp. in Tanzania. Report of Grain Legume Stored Pest Survey. Ministry of Agriculture, Dar-es-Salam, Tanzania. 9 pp.

Nene, Y.L., Hall, S.D., Sheila, V.K. 1990. The pigeonpea. Nene, Y.L., Hall, S.D., Sheila, V.K. (Eds.), ICRISAT, CAB International, Wallingford, UK. pp. 1-13.

Silim Nahdy, M. 1995. Biotic and abiotic factors influencing the biology and distribution of common storage pests of pigeonpea. Ph.D Thesis. University of Reading, UK. pp. 257.

Silim Nahdy, M., Silim SN, , Ellis, R.H., Smith, J. 1997. Field infestation of pigeonpea (Cajanus cajan (L.) Millsp.) by Callosobruchus chinensis (L.) in Uganda. (In press).

Singh, U., Jambunathan, R. 1990. Pigeonpea: post-harvest technology. In: The Pigeonpea. Nene, Y.L., Hall, S.D., Sheila, V.K. (Eds.), ICRISAT, CAB International, Wallingford, UK. pp. 435-455.

Southgate, B.J. 1978. The importance of the Bruchidae as pests of grain legumes, their distribution and control. In: Pests of Grain Legumes: Ecology and Control. Singh, S.R., van Emden, H.E., Taylor, A.T. (Eds.), Academic Press, London, UK. pp. $219-229$.

Taylor, T.A. 1981. Distribution, ecology and importance of bruchids attacking grain legumes in Africa. In: The ecology of bruchids attacking legumes (pulses) Labeyrie, V. (Ed.), Junk Publishers, The Hague. pp. 199-203.

Tuwafe, S., Silim, S.N., Laxman, Singh. 1994. ICRISAT/AfDB pigeonpea improvement project in Eastern and southern Africa. In: Pigeonpea Improvement in E. and S. Africa-Ann. Res. Planning Meeting. Silim SN, Tuwafe S, Laxman Singh (Eds) 1993, 2527 Oct. 1993, Bulawayo, Zimbabwe. ICRISAT, Patancheru, India. pp. 10-118.

Van Huis, A., 1991. Biological methods of bruchid control in the tropics. A review. Insect Science and Its Application $12,87-102$.

Yoshida, T. 1990. Historical review of bruchid studies in Japan. In: Bruchids and Legumes: Economics, Ecology and Co-evolution. Fujii, K. (Ed.), Kluwer Academic Publishers, The Hague, Netherlands. pp. 1-24. 